\title{
Risk financing choices of Polish companies - survey results
}

\section{Introduction}

The choice of appropriate risk control tools is essential in the risk management process. Physical risk control tools allow to reduce the probability of risk or reduce the scale of physical damage. Financial risk control tools are implemented with the aim to counterbalance the negative impact of financial consequences of risk. Thus, these tools are alternatively referred to as risk financing tools. Obviously, the corporate decisions on the application of financial risk control tools are related to financial management issues, as the choice of appropriate risk financing is relevant for the cost of capital and may enhance value creation. In this context, risk financing becomes an important element of a company's financial decision-making process and may influence the efficiency of its performance.

The paper presents and discusses the results of a survey which aimed at examining the problem of the choices of risk financing methods, as related to corporate finance decision-making. Taking into account the dilemmas of the use of risk retention, as well as the impact of the cost of insurance risk transfer, the study has asked several questions on the corporate preferences and financially-oriented constraints of each risk financing tool.

The study contributes to the existing debate by providing an insight into the motives behind the use of risk transfer or risk retention that are relevant in the real business environment. The motives behind the use of risk transfer are relatively well explored in the literature, both in the individual and corporate context. However, there are virtually no studies that address the risk retention decisions. In particular, the problem of corporate risk retention limits remains unexplored. The study focuses on Poland, where the risk management has just started to grow 
on interest. Up to date, there were several risk management related researches, but of very diversified scope. These mostly focused on risk awareness, particular types of risk (e.g. exchange rate risk) or the use of risk transfer tools ${ }^{1}$.

The paper is organized as follows. The first section outlines the conceptual framework of the study, by addressing the application of risk retention and insurance risk transfer and the consequences of their use from corporate finance theory point of view. The second section discusses the research design and methodology of the study, and develops the researched problems as given decisive situations. The third section presents and discusses the results. The fourth section concludes.

\section{Conceptual framework}

In the risk management process, risk analysis is followed by the choice of appropriate risk control tools. Financial risk control tools allow to counterbalance the negative financial impact of loss. There are two basic financial risk control tools - risk retention and risk transfer. Risk retention occurs if the company covers the financial burden of loss by itself. Risk transfer means that the negative financial consequences of risk are contractually transferred to a third party, which is obliged to ensure the inflow of capital in the case of risk occurrence [Rejda 2001, Vaughan and Vaughan 2003, Culp 2006].

A company retains the risk unconsciously if it failed to identify the risk or simply neglected the potential of risk outcomes and did not implemented any other risk financing method. From risk management point of view, however, the conscious risk retention is in focus. This refers to the situation when a company intentionally chooses to retain the risk, and this decision is based on appropriate computations. Conscious risk retention is followed by financing decisions which lead to (a) earmarked financial reserves (hold in liquid assets, formally or informally) and/or (b) the pre-negotiation of external financing inflow in the case

\footnotetext{
${ }^{1}$ The problem of risk retention was signalised only in the study by Strupczewski and Thlon [2014], sample $\mathrm{N}=386$, in the context of the boundaries of risk tolerance. The managerial awareness of risk-management related issues was examined by Bizon-Górecka [2007] - sample of 254 companies; Tymoczko [2009] examined the foreign exchange risk management $(\mathrm{N}=800$, as an element of a questionnaire by the National Bank of Poland), risk management practices in SMEs were examined by Kasiewicz et al. [2012], sample $N=60$ companies; Domański [2014] examined risk management in non-profit organisations $(\mathrm{N}=235)$. Since 2009, Poland has been included in the biannual global risk management survey by AON; however the results were presented jointly for financial and non-financial companies (in 2009 on sample of $\mathrm{N}=106$, in 2011 on sample of $\mathrm{N}=73$ and in 2013 on sample of $\mathrm{N}=234$ [Słobosz and Ziomko 2009, Słobosz et al. 2011, Przywecki et al. 2013].
} 
of the negative impact of risk on company's financial situation (e.g. credit lines) [Vaughan and Vaughan 2003, Culp 2006].

Risk transfer is often presented as the alternative to risk retention. Accordingly, the benefits of risk transfer are explained by highlighting the shortcomings of risk retention. First of all, while a company decides to retain the risk, there is always a problem that the earmarked reserves will be insufficient to cover the financial consequences of risk on its occurrence. Further, it requires a discipline both in gathering the reserves, and in safeguarding their volume. These capital reserves might be perceived as the source of funds for the purposes other than risk coverage (the cookie jar effect). From financial theory point of view, there is also a quest on the efficiency of setting aside the cash which may be used for operating purposes and value creation. This is particularly questionable in the context of signaling theory (developed by Ross 1977). On one side, cash reserves may generate positive signals (as so-called financial slack), but on the other may be perceived negatively in the efficiency and transparency context. It is worth noting that from financial theory point of view, the retained risk is also the risk ultimately to be borne by the company's owners and thus may influence their expected rates of return (and the cost of capital).

In the insurance literature it is highlighted that risk transfer allows to avoid the above listed problems of risk retention. Instead, a company transfers the risk to third party and in exchange pays the premium. The risk transfer contract means the inflow of funds in the case of the financial consequences of risk occurrence. There are two main methods of risk transfer - the insurance risk transfer and the non-insurance risk transfer (the hedging with derivatives) [Rejda 2001, Vaughan and Vaughan 2003]. In this study, however, only the insurance risk transfer will be taken into account.

The literature relatively largely discusses the reasons behind the corporate decisions to insure or not to insure. In the individual dimension, the willingness to purchase insurance is usually explained by risk aversion. In other words, the risk-averse individuals are purchasing insurance to protect themselves. By doing so, they replace worries and fears with the reasonable cost of insurance premium. The traditional views explaining this phenomenon rely on the expected utility of insurance [Gollier 2000, Machina 2000, Schlessinger 2000, Outreville 2014]. Some recent views add to the discussion the behavioral context, by referring the impact of the possibility effect (as explained by the fourfold pattern, proposed by the prospect theory). In the event of negative risk outcomes and losses, the emotional effect of the fear of large losses causes risk aversion and leads to the acceptance of unfavourable settlements. This explains why many individuals are willing to pay much more for insurance than its expected value. For the insurance 
business, the possibility effect produces favourable business conditions to make profits [Kahneman 2011].

The risk aversion, however, cannot fully explain the reasons why companies use insurance risk transfer. The separation of ownership and managerial control allows investors (company's owners) to manage the risk in a more effective way by portfolio diversification. In order to explain the motivations behind insurance risk transfer, the financial theory paradigms are often recalled. In general, it is highlighted that the implementation of insurance risk transfer helps a company to reduce certain costs: (a) the costs of corporate taxes (in the case of the convex taxation), (b) the financial distress costs, and (c) agency and information asymmetry costs [Mayers and Smith 1982], MacMinn [1987], MacMinn and Han [1990], Grace and Rebello [1993]. Generally speaking, from the corporate finance point of view, one of the core benefits of insurance risk transfer is the reduction of cash flow volatility due to the financial outcomes of risk. The financial outcomes of risk may lead to financial distress and increase the bankruptcy costs. Also, facing the financial consequences of risk, the company may be forced to postpone the planned investments (which refers to the underinvestment theory, as noted by Myers in 1977). As found by Smithson and Simkins [2005], the empirical studies usually address the cash flow volatility and the risk transfer by the use of derivatives (as an equivalent of risk transfer), in order to show the connection between value creation and risk transfer implementation.

As mentioned, risk retention and risk transfer are usually presented as two alternative risk financing techniques. The general recommendations on the use of retention or transfer are often matched with the possible burden of financial loss due to the height of risk frequency and risk severity. If the risk is not severe, but frequent, then retention is possible (in particular, the loss might be calculated as the cost of running the business, due to its high frequency). If the risk is severe, but not frequent, then the risk transfer is the recommended option [Ratliff and Hanks 1992, Borghesi and Gaudenzi 2013].

In practice, the particular risk financing tools implemented in a company are the combination of retention and transfer in certain proportions. There are many reasons behind these combinations. Some of these reasons are driven by external factors (e.g. the capacity of insurance market), whereas others by internal factors (e.g. the retention capability of the company, conscious and intentional decision of a company). There is also a growing number of innovations, which use the effectiveness of combining risk retention with risk transfer (the ARTs solutions, captives in particular). It is worth noting that the proponents of these innovations often encourage the implementation of risk retention with the potential of reducing insurance premium [Kloman and Rosenbaum 1982, Culp 2006]. 


\section{Research design and methodology}

Taking into account various (and sometimes contradicting) arguments for or against the use of risk retention and insurance risk transfer, this study examines the set of data referring some aspects of companies' choices between risk retention and risk transfer. The data were obtained in a survey dedicated to a wider range of issues within the relationship between corporate financial decision making and risk management issues. The survey was conducted in 2013 on a sample of non-financial companies operating in Poland (PAPI technique, conducted by professional research center). The questionnaire was directed to the sample of 250 companies which have formally implemented risk management procedure (in most of the cases with the help of consultants). The answers were given by the members of management boards responsible for managing risk or chief risk officers, if appointed. These assumptions helped to avoid two core limitations of the interview of a research method: (a) the artificiality of the interviewer and (b) wrong level of entry [Myers 2013]. Finally, 157 questionnaires were subject of further analysis (after the verification of completeness of answers and the legal and branch status of the company). Financial companies were excluded from the sample due to the impact of regulatory requirements on their risk management practices. It is particularly relevant while considering the risk-financing strategies (in this retention-transfer preferences).

Figures 1 and 2 present the basic characteristics of the interviewed companies. Taking into account the extent of risk management integration (Fig. 1), the majority of these companies were labelled as moderate. These companies declared that risk management accompanies most areas of their business operations. Accordingly, the companies with considerably low scale of risk management integration were labeled as low. These companies declared that risk management implementation is related only to several business activities. The holistic approach to risk management was declared by $18 \%$ of the interviewed companies (which were labelled as high), where risk management scheme was related to all business activities.

Other firm-specific characteristics taken into consideration were related to companies' size. According to Verbano and Venturini [2013], there is a problem of the specifics of risk management in SMEs, which has gained wide research attention recently. Usually, the size of a company is perceived by the number of employees or volume of annual revenues (or both). As it can be seen in Figure 2, more than a half of the interviewed companies were the small and medium-sized ones (and 72 fulfilled both criteria of SMEs).

As mentioned above, this study refers only to a chosen set of data obtained in the survey. In particular, it revises in depth three questions of the survey. Each 
Figure 1

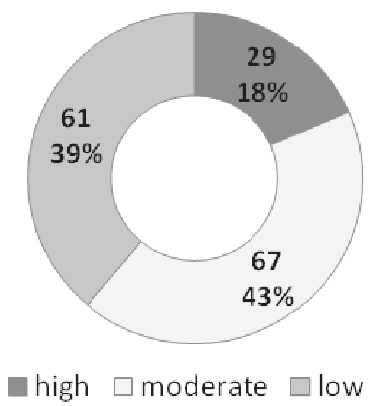

Sample characteristics - the scale of risk management integration in the surveyed companies

a

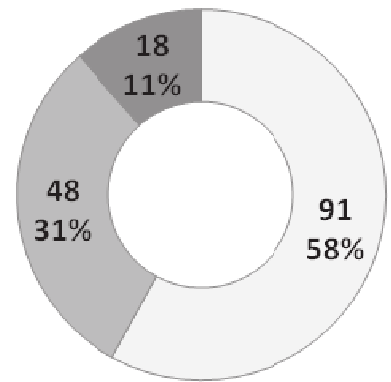

$\square$ up to 249 (SME)

$\square 250-2499$ (large)

2500 and more (v.large)

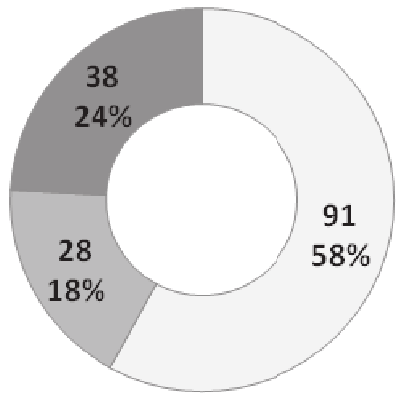

$\square$ up to 200 (SME)

$\square 200-500$ (large)

500 and more (v.large)

Figure 2

Sample characteristics - size of the surveyed companies: a - number of employees, b - annual revenues in million PLN

of these three questions referred to one given decisive situation, with a clearly outlined decisive context and a given number of decisive options. In this element, the construction of the questions was inspired by the examples of puzzles or paradoxes presented in the literature within the ambiguity of decision making under risk. These examples usually provide a clear information on the chance (probability) and reward and discover the bias of human cognition (e.g. Bernoulli paradox, or Allais paradox). In addition, the context of these decisions is also relevant (not winning, but loosing), and the difficult decisions are "in the middle" [Kahneman 2011].

The formula of the three questions in focus referred to the advice given by the respondents (hereafter - managers). In other words, managers were not asked 
about their personal views and opinions, but on giving the recommendation of one of the given options. Accordingly, instead of asking "What would you do?", there were questions asking "What should your company do?". Obviously, to some extent these recommendations are preceded by the managers' views, opinions or personal experience. However, the surveyed managers were in power of taking similar decision in their companies. By highlighting the advisory context of their responses, it can be assumed that their views influence the real choices of the represented company.

The first decisive situation (hereafter Situation 1) was related to the choice between risk retention and insurance risk transfer as the alternatives. As it was highlighted in the previous section of the paper, the literature often discusses the limitations of risk retention and in this context explains the benefits of insurance transfer. It is particularly visible in the insurance-related literature. Also, from corporate finance perspective, the risk retention is disputable (efficiency of reserves, risk ultimately to be borne by company's owners). Thus, insurance transfer seems to be a more recommended tool as compared to risk retention. In this context, the two research questions were asked:

- Question 1: Have the managers' recommendations shown the preference of insurance transfer to risk retention?

- Question 2: Were these recommendations related to the characteristics of the represented companies (level of risk management integration and size)?

The second decisive situation (hereafter Situation 2) referred to financiallyoriented constraints of risk retention, whereas the third (hereafter Situation 3) - to financially-oriented constraints of risk transfer. Reasonable risk retention requires to set aside cash reserves (either in formal or informal way) or to ensure an external funding facility. Intuitively, the volume of cash reserves or external funding should correspond with the possible size of the loss, by providing the full coverage of the loss (as the optimum). Insurance risk transfer is judged as reasonable solution, depending on its price - the insurance premium, which simply shows the contribution of the insured in the insurance pool. This problem refers to the possibility effect, as defined in the "fourfold pattern" of prospect theory (addressed above). These reflections have led to the further two research questions:

- Question 3: Were the managers' recommendations relatively consentaneous in the context of financially-oriented constraints of risk retention/insurance transfer?

- Question 4: Were these recommendations related to the characteristics of the represented companies (level of risk management integration and size)? 


\section{Results and discussion}

\section{Risk retention and insurance transfer as the alternatives (Situation 1)}

In the first decisive situation the managers were asked about their recommendation on the choice of retention or insurance, provided that the company is exposed to risk which may result in a potential loss of PLN 5 million. Additionally, respondents were informed that the company is able to cover all these losses by itself (from the liquid assets reserves and within the pre-negotiated access to external funding). The given decisive options were:

a) to insure the risk (with the insurance sum of PLN 5 million) - which means full insurance,

b) to insure the risk, but with the insurance sum lower than PLN 5 million and the possible limitations of insurance cover - which means partial insurance,

c) to not insure the risk - which means to retain the risk.

As it can be seen in Table 1, only five managers recommended to retain the risk. The remainder 152 were of the opinion that a company should purchase insurance, and the fraction of the managers who were for full or partial insurance was similar. These findings fully reflect the supposition that risk retention is less popular as compared to risk transfer. Also, these results may be regarded as some support for phenomenon of the possibility effect.

Table 1

The companies retention-transfer decisions, as recommended by the interviewed managers $(\mathrm{N}=157)$

\begin{tabular}{|l|c|c|}
\hline Decisive options & Frequency & Percentage [\%] \\
\hline Full-insurance cover & 74 & 47.13 \\
\hline Partial insurance cover & 78 & 49.68 \\
\hline Retention & 5 & 3.18 \\
\hline In total & 157 & 100.00 \\
\hline
\end{tabular}

Source: Own study based on questionnaire results.

\section{Financially-oriented constraints of risk retention (Situation 2)}

The second decisive situation was related to the managers' recommendations on the appropriate level of retention, as related to the possible loss. The context of the question clearly addressed the problem of the desired level of retention, by asking what should be the height of liquid assets set aside, relative to the value of the possible loss, to make the retention decision reasonable. 
As it can be seen in Table 2, a relatively high fraction (more than a half) of managers indicated the level of 50 or $100 \%$. These results seem surprising, taking into account that in the previous situation most of the managers were somehow against the retention. However, to some extent, it confirms the fact that retention is less popular that transfer. As a result, the managers recommend much lower levels of retention as supposed. One explanation of these results might be the managerial awareness of the negative signals generated by the cash set aside (and not involved in operating activity). Another explanation may be the unconscious treatment of retention as an element of risk management program, and thus $30 \%$ of respondents recommend to set aside cash enough for covering only the $50 \%$ of possible loss. The remainder managers (ca. 44\%) indicated the relation of more than $100 \%$. It is worth noting that ca. $20 \%$ recommended a very safe level of $300 \%$ or more, which may be, however, driven by their personal risk aversion.

\section{Table 2}

The level of liquid assets relative possible loss, as recommended by interviewed managers $(\mathrm{N}=157)$

\begin{tabular}{|l|c|c|}
\hline Decisive options & Frequency & Percentage [\%] \\
\hline $50 \%$ & 48 & 30.57 \\
\hline $100 \%$ & 42 & 26.75 \\
\hline $150 \%$ & 22 & 14.01 \\
\hline $200 \%$ & 10 & 6.37 \\
\hline $250 \%$ & 1 & 0.64 \\
\hline $300 \%$ & 29 & 18.47 \\
\hline more than $300 \%$ & 5 & 3.18 \\
\hline In total & 157 & 100.00 \\
\hline
\end{tabular}

Source: Own study based on questionnaire results.

\section{Financially-oriented constraints of risk transfer (Situation 3)}

In the third situation, the managers were asked about the maximum acceptable price for the possibility to insure the risk. The insurance price was reflected as a fraction of the possible loss. This situation revises also the problem of retention, but in a hidden context.

As presented in Table 3, ca. 15\% of the managers recommended the lowest possible fraction of $0.01 \%$, and the following $32 \%$ indicated the fraction of $1 \%$. These answers might be perceived as the recommendation to retain the risk if the insurance premium is higher than $0.01 \%$ or $1 \%$ of the possible loss. Nearly a half of the respondents, however, indicated higher fractions. These judgements may 


\section{4}

\section{Table 3}

The maximum payment for insurance transfer, as recommended by the interviewed managers $(\mathrm{N}=157)$

\begin{tabular}{|l|c|c|}
\hline Decisive options & Frequency & Percentage [\%] \\
\hline Up to $0.01 \%$ & 24 & 15.29 \\
\hline Up to $1 \%$ & 51 & 32.48 \\
\hline Up to $5 \%$ & 58 & 36.94 \\
\hline Up to $10 \%$ & 24 & 15.29 \\
\hline More than $10 \%$ & 0 & 0 \\
\hline In total & 157 & 100.00 \\
\hline
\end{tabular}

Source: Own study based on questionnaire results.

be of course influenced by the personal experience of the respondents, as regards the height of the insurance premiums paid by their companies. In particular, the companies which purchase non-standard coverage, or have a significant loss experience, may face (in practice) higher levels of insurance premiums. However, it may also be treated as another support of the phenomenon of the possibility effect (once again confirming the tendency to insure rather than retain the risk).

\section{Relationship with firm-specific characteristics}

As it can be seen in Table 4, the correlations between the recommended decisive options, in the given decisive situations, and the firm specific characteristics were weak to very weak. However, the application of Kruskal-Wallis test ${ }^{2}$

\section{Table 4}

Relationship between the analysed variables

\begin{tabular}{|l|c|c|c|c|c|c|}
\hline \multirow{2}{*}{ Variables } & \multicolumn{3}{|c|}{ Cramer's V coefficients } & \multicolumn{2}{c|}{ p-value; Kruskal-Wallis test } \\
\cline { 2 - 7 } & $\mathrm{RM} / \mathrm{I}$ & $\mathrm{E}$ & $\mathrm{R}$ & $\mathrm{RM} / \mathrm{I}$ & $\mathrm{E}$ & $\mathrm{R}$ \\
\hline $\begin{array}{l}\text { Retention-transfer } \\
\text { choices }\end{array}$ & 0.225 & 0.218 & 0.187 & 0.928 & $0.087^{*}$ & 0.172 \\
\hline $\begin{array}{l}\text { Retention: financial } \\
\text { constraints }\end{array}$ & 0.094 & 0.163 & 0.184 & 0.613 & $0.033^{* *}$ & $0.001^{* * *}$ \\
\hline $\begin{array}{l}\text { Insurance transfer: } \\
\text { financial constraints }\end{array}$ & 0.155 & 0.224 & 0.176 & 0.968 & 0.120 & $0.043^{* *}$ \\
\hline
\end{tabular}

RM I - the scale of risk management integration, $\mathrm{E}$ - the size of companies measured by the number of employees, $\mathrm{R}$ - the size of companies measured by revenues; Statistical signifi-

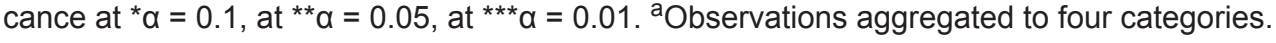
Source: Own eleboration.

\footnotetext{
${ }^{2}$ Kruskal-Wallis test is a non-parametric method (called one-way ANOVA on ranks). The test is applicable for comparing two or more independent samples. The Pearson $\chi^{2}$ test could not be used due to low number of observations in some categories.
} 
revealed some statistically significant dependencies. The firm-specific characteristics were treated as the independent variables. Accordingly, it can be stated that the managers recommendations (risk retention/transfer choices, the financial constraints of risk retention and financial constraints of risk transfer) were related to company's size. There were no dependencies in the case of the scale of risk management integration.

\section{Conclusions}

The study addressed three decisive situations faced by the respondents-managers, as regards selected issues of risk retention/transfer decisions. In this context, the four research questions were asked. In the situation addressing the choice between retention and transfer, the study has shown the preference given to insurance risk transfer (Question 1), as it was expected. It might be driven by the attention given to the insurance risk transfer in the literature, and the context of discussing its benefits over risk retention. The study has shown that that the manager's recommendations cannot be judged as coinstantaneous facing the options of financially-oriented constraints of risk retention or insurance transfer (Question 3). The data has shown that there were relatively large fractions of the managers indicating both the edge and the middle options. The study has also found that the recommendations of the interviewed respondents were connected with the size of their company (Questions 2 and 4).

The study relies on the results of the questionnaire which is always related to the overall limitations of the interview and sample representativeness. Thus, the study was exposed to the risk of a bias due to the artificiality of the interviewer, level of entry or ambiguity of language (although the attention was paid to avoid these). Another important limitation is related to the constraints of the relatively lower familiarity, understanding and practice of risk management process in Poland, as one of the Eastern European countries. However, given the scarcity of risk management researches in these countries (as compared to western countries), this study contributes to filling in this research gap. Thus, the results may provide some insight into the risk management practice and its financially relevant consequences in Poland, as well as provide a comparative basis for similar studies in other post-transition countries.

\section{References}

BIZON-GÓRECKA J., 2007: Modelowanie struktury systemu zarzadzania ryzykiem w przedsiębiorstwie - ujęcie holistyczne, Towarzystwo Naukowe Organizacji i Kierownictwa, Bydgoszcz. 
BORGHESI A., GAUDENZI B., 2013: Risk Management. How to Assess, Transfer and Communicate Critical Risks, Springer, Milan.

CULP C., 2006: Structured Finance and Insurance. The ART of Managing Capital and Risk, John Wiley \& Sons, Hoboken.

DOMAŃSKI J., 2014: Zarzadzanie ryzykiem w organizacjach non profit, Oficyna Wydawnicza Wolters Kluwer Polska, Warszawa.

GOLLIER CH., 2000: Optimal Insurance Design: What Can We Do With and Without Expected Utility, [in:] G. Dionne (ed.), Handbook of Insurance, Kluwer Academic Publishing, Boston, 91-115.

GRACE M.F., REBELLO M.J., 1993: Financing and the Demand for Corporate Insurance, The Geneva Papers on Risk and Insurance Theory 18(2), 147-172, doi: 10.1007/ BF01111467.

KAHNEMAN D., 2011: Thinking Fast and Slow, Farrar, Straus and Giroux, New York.

KASIEWICZ S., LEPCZYŃSKI B., GÓRSKI P., 2012: Zarzadzanie ryzykiem jako wyzwanie strategiczne przedsiębiorstw w okresie globalnego kryzysu, [in:] S. Kasiewicz (ed.), Strategie przedsiębiorstw i zarzadzanie ryzykiem $w$ warunkach kryzysu gospodarczego. Perspektywa sektora MSP, Instytut Badań nad Gospodarką Rynkową, Gdańsk, 93-139, http://www.pte.pl/pliki/2/1/IBnGR_Publikacja.pdf.

KLOMAN H.F., ROSENBAUM D.H., 1982: The Captive Insurance Phenomenon: A Cautionary Tale?, Geneva Papers on Risk and Insurance 7(23), 129-151.

MACHINA M.J., 2000: Non-Expected Utility and the Robustness of the Classical Insurance Paradigm, [in:] G. Dionne (ed.), Handbook of Insurance, Kluwer Academic Publishing, Boston, 38-90.

MacMINN R.D., 1987: Insurance and Corporate Risk Management, Journal of Risk and Insurance 54(4), 658-677, doi: 10.2307/253115.

MacMINN R., HAN L.M., 1990: Limited Liability, Corporate Value and the Demand for Liability Insurance, Journal of Risk and Insurance 57(4), 581-607, doi: 10.2307/252945.

MAYERS D., SMITH C.W., 1982: On the Corporate Demand for Insurance, Journal of Business 55(2), 281-269, doi: 10.1007/978-94-015-7957-5_9.

MYERS S.C., 1977: The Determinants of Corporate Borrowings, Journal of Financial Economics 5, 147-175.

MYERS M.D., 2013: Qualitative Research in Business and Management, Sage Publications, London.

OUTREVILLE J.F., 2014: Risk Aversion, Risk Behavior, and Demand for Insurance: A Survey, Journal of Insurance Issues 37(2), 158-186, http://www.jstor.org/stable/43151298.

RATLIFF R., HANKS S., 1992: Evaluating Risk, Managerial Auditing Journal 7(5), doi: 10.1108/02686909210017883.

REJDA G.E., 2001: Principles of Risk Management and Insurance, Addison Wesley, Longman, New York.

ROSS S.A., 1977: The Determination of Financial Structure: The Incentive-Signaling Approach, Bell Journal of Economics 8(1), 23-40.

SCHLESINGER H., 2000: The Theory of Insurance Demand, [in:] G. Dionne (ed.), Handbook of Insurance, Kluwer Academic Publishing, Boston, 131-151. 
SŁOBOSZ J., ZIOMKO R., 2009: Zarzqdzanie ryzykiem i ubezpieczeniami w firmach w Polsce. Raport Aon Polska, http://www.polrisk.pl/wp-content/uploads/2013/05/AONPolska_Zarzadzanie-ryzykiem-i-ubezpieczeniami-2009.pdf.

SŁOBOSZ J., ZIOMKO R., PRZYWECKI M., 2011: Badanie zarzadzania ryzykiem i ubezpieczeniami $w$ firmach w Polsce. Raport Aon Polska 2011/2012, http://www.polrisk. $\mathrm{pl} / \mathrm{wp}$-content/uploads/2013/05/AON-raport-2011-end.pdf.

SMITHSON C., SIMKINS B.J., 2005: Does Risk Management Add Value? A Survey of the Evidence, Journal of Applied Corporate Finance 17(3), 8-17, doi: 10.1111/j.17456622.2005.00042.x.

STRUPCZEWSKI G., THLON M., 2014: Wykorzystanie techniki zatrzymania ryzyka przez średnie $i$ duże przedsiębiorstwa $w$ Polsce $w$ świetle badań ankietowych, Wiadomości Ubezpieczeniowe 59-84, https://www.piu.org.pl/public/upload/ibrowser/Wiadomosci\%20Ubezpieczeniowe/WU\%203-2014.pdf.

TYMOCZKO I., 2009: Sposoby zabezpieczania się polskich przedsiębiorstw niefinansowych przed ryzykiem kursowym, Bank i Kredyt 40(3), 71-92. http://bankikredyt.nbp.pl/home. aspx?f=/content/2009/03/bik_03 2009 pl.html.

VAUGHAN E.J., VAUGHAN T., 2003: Fundamentals of Risk and Insurance, John Wiley \& Sons, New York.

VERBANO C., VENTURINI K., 2013: Managing Risks in SMEs: A Literature Review and Research Agenda, Journal of Technology Management and Innovation 8(3), 186-197, doi: http://dx.doi.org/10.4067/S0718-27242013000400017.

\section{Abstract}

The paper presents and discusses the results of the survey which aimed at examining the choices of risk financing methods in Polish non-financial companies. The basic alternatives in risk financing are risk retention and insurance risk transfer. Risk financing decisions remain related to corporate financial decision-making process (due to the impact on the cost of capital and value creation). The paper discusses the obtained survey results in three decisive contexts (situations): risk retention and transfer as the alternatives, financial constraints of risk retention and financial constraints of risk transfer. It was found that the surveyed companies have showed the preference of risk transfer and these preferences were related to their size.

Key words: risk management, risk financing, corporate finance, financial decision-making, retention, insurance 


\title{
Wybór metod finansowania ryzyka w polskich przedsiębiorstwach - wyniki badań ankietowych
}

\begin{abstract}
Abstrakt
Artykuł prezentuje wyniki badań ankietowych, których celem było zbadanie zastosowania metod finansowania ryzyka w przedsiębiorstwach. Retencja ryzyka i ubezpieczenie często są przedstawiane w literaturze jako skrajne alternatywy w obrębie możliwości finansowania ryzyka. Finansowanie ryzyka jest ważnym elementem decyzji finansowych przedsiębiorstwa, wpływającym również na efektywność jego działania (przez kategorię kosztu kapitału). Badania ankietowe przeprowadzono na próbie polskich przedsiębiorstw niefinansowych. Artykuł odnosi się do wyników tych badań w obszarze trzech sytuacji decyzyjnych: wyboru między retencją a ubezpieczeniem (jako alternatywami), finansowych ograniczeń dla zastosowania retencji oraz finansowych ograniczeń dla zastosowania transferu. Wyniki badań wskazują, że badane przedsiębiorstwa preferowały ubezpieczenie, co miało słaby (ale istotny statystycznie) związek $\mathrm{z}$ ich wielkością.
\end{abstract}

Słowa kluczowe: zarządzanie ryzykiem, finansowanie ryzyka, finanse przedsiębiorstw, podejmowanie decyzji finansowych, retencja, ubezpieczenie 